\title{
p53-based Anti-cancer Therapies: an Empty Promise?
}

\author{
Nikolas Desilet ${ }^{1}$, Tessa N. Campbell ${ }^{2}$ \\ and Francis Y.M. Choy ${ }^{1 *}$ \\ ${ }^{1}$ Department of Biology, University of Victoria, Victoria, BC, \\ Canada \\ ${ }^{2}$ Southern Alberta Cancer Research Institute, Department \\ of Oncology, University of Calgary, Calgary, AB, Canada
}

\begin{abstract}
Since its discovery in 1979, p53 has become the focus of intensive cancer-based research in laboratories around the world. The p53 protein mediates critical cellular functions including the response to genotoxic stress, differentiation, senescence, and apoptosis, and has been shown to be mutated in a large proportion of human cancers. These observations led many to speculate that targeting the p53 pathway would result in the development of successful anticancer treatments. In spite of this, 30 years later, p53 has yet to fulfill this promise. However, new insights into small molecule combination therapies, microRNA regulation, structuring of clinical trials, and potential involvement in stem cell regulation may help p53 reach its potential.
\end{abstract}

\section{The Promise}

The p53 protein was identified in 1979 by coimmunoprecipitation of p53 with T-antigen in SV40transformed cells (Chang et al., 1979; Kress et al., 1979; Lane and Crawford, 1979; Linzer and Levine, 1979; Melero et al., 1979). It was further noted that the p53 protein was overexpressed not only in SV40-transformed cells, but also in carcinoma cell lines (Linzer and Levine, 1979; for a detailed historical review of p53, see Hainaut and Wiman, 2009).

Early work implicated p53 as an oncogene (Eliyahu et al., 1984; Parada et al., 1984); however, it was subsequently determined that a mutant version of p53 was utilized in these studies (Hinds et al., 1989). Successive studies using wildtype p53 supported the conclusion that p53 acts instead as a tumour suppressor (Baker et al., 1989; Finlay et al., 1989; Hinds et al., 1989). Following these discoveries, p53 was dubbed "guardian of the genome" (Lane, 1992) and Science's "Molecule of the Year 1993".

Since then, p53 has been shown to play a role in response to genotoxic stress, differentiation, senescence, and apoptosis, and is one of the most commonly altered proteins in human cancer (Chari et al., 2009). Consequently, many laboratories have dedicated considerable time and resources with the intention of developing therapies aimed at restoring wildtype p53 activity in cells with mutated p53 or by inhibiting a key negative regulator of $p 53$, such as murine double minute 2 (MDM2; Vazquez et al., 2008). Though a wealth of information has been accumulated in this area, p53-based research has not yet had a wide impact on cancer management and therapy (Hainaut and Wiman,

\section{*Corresponding author: Email: fchoy@uvic.ca}

\section{The Promise}

-p53 is a critical tumour suppressor -p53 mediates response to genotoxic stress, differentiation, senescence, and apoptosis -p53 is one of the most commonly altered proteins in cancer -p53 is the "guardian of the genome" -p53-based therapies can be effective anticancer treatments

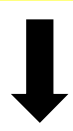

\section{The Reality}

-p53 reactivation in animal models promotes tumour clearance

-main therapeutic approaches: p53 viral-mediated gene or oncolytic therapy and p53 pharmacological modulation

-obstacles noted: premature aging, unwanted side effects in normal tissues, appearance of p53-resistant tumours, establishment of optimal dose and time of treatment, standardization of administration in the clinical setting -after $\mathbf{3 0}$ years, p53 has yet to make a significant clinical impact on cancer

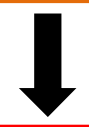

\section{The Future}

-combination therapy as a multi-faceted approach -microRNA regulation of p53 as a novel treatment -new role for p53 identified in stem cell propagation

-coordination of large-scale structured clinical trials and generation of comprehensive p53 databases

-p53-based therapies are on their way to fulfilling their promise of being effective anti-cancer treatments

Fig. 1. The promise, the reality, and the future of p53based anti-cancer therapies.

2009) and the question remains as to whether the promise of p53-based anti-cancer treatments will turn out to be an empty one (Figure 1).

\section{The Reality}

Numerous approaches have been applied to generate p53based anti-cancer therapies. Such approaches include: retrovirus- or adenovirus-mediated gene therapy to restore 
p53 function, killing of p53-deficient cells with modified adenoviruses, and pharmacological modulation of p53 protein functions (Bouchet et al., 2006). Studies have also taken place to identify drugs and mechanisms that activate p63 and p73, since these proteins are not mutated in cancers and as such are potential candidates for replacing p53 in p53-deficient cells (Alsafadi et al., 2009).

Recent genetic studies in mouse models have shown that reactivation of the p53 pathway in tumours with reduced or no p53 activity promotes tumour clearance, renewing interest in and providing further strong evidence for designing anti-cancer drugs that restore p53 function (Ventura et al., 2007; Xue et al., 2007; Vazquez et al., 2008; Shangary and Wang, 2009). Among the different strategies for restoring p53 function, targeting the MDM2-p53 interaction by small molecules has proven to be popular. MDM2 has been shown to inhibit p53 by regulating its subcellular location, its stability, and its transactivation function (Vazquez et al., 2008; Shangary and Wang, 2009). Historically, disruption of protein-protein interactions has been a daunting task due to the typically large binding region of the protein partners. However, the MDM2-p53 interaction has been mapped to a small, well-defined interface, opening the door to the possibility of interference by small molecule inhibitors. Different approaches have been used to identify and design small-molecule inhibitors of the MDM2-p53 interaction. These include: 3D database screening of large chemical libraries, experimental screening of chemical libraries, and structure-based de novo design (Shangary and Wang, 2009). These approaches have generated a number of potential therapeutic agents (Nutlins, benzodiazepines, reactivation of $\mathrm{p} 53$ and induction of tumour cell apoptosis [RITA], spiro-oxindoles, and quinolinols) for interference with the MDM2-p53 interaction, however, the efficacies of such treatments in humans remain to be determined (Vazquez et al., 2008).

Interestingly, accumulating observations of p53 activity in vivo in experimental animals indicate that the same p53 tumour suppressive functions can be harmful under conditions of systemic genotoxic stress such as total body irradiation or injection of genotoxic anti-cancer drugs (Gudkov and Komarova, 2007). By comparing tumour models differing in stromal p53 status, Burdelya et al. (2006) showed that tumours with p53-deficient stroma were significantly more sensitive to experimental chemoand radiotherapy than tumours with wildtype p53 stroma. Thus, temporary and reversible suppression of p53 may be beneficial for prevention and treatment of acute conditions associated with severe genotoxic stress (Gudkov and Komarova, 2007).

Despite the intensive p53-based therapeutic research and numerous discoveries presented above, reality dictates that significant challenges and unresolved issues need to be addressed before p53-targeted therapies find clinical application. Examples of such obstacles include: premature aging, unwanted side effects in normal tissues, appearance of p53-resistant tumours, establishment of optimal dose and time of treatment, and standardization of administration in the clinical setting (Bouchet et al., 2006; Fuster et al., 2007).

\section{The Future}

Recent discoveries complement the last 30 years of p53based research. Insights into small molecule combination treatments, microRNA regulation of p53, potential involvement of p53 in stem cell regulation, and coordinated restructuring of clinical trials with compatible comprehensive databases will likely accelerate the development of p53based anti-cancer therapies.

Due to the recognized heterogeneous nature of cancer, combination therapies are increasingly being proposed as more effective strategies. In the case of p53-based treatment approaches, promising results have been seen by combining small molecule inhibitors with various other anti-cancer agents. For example, Graat et al. (2007) demonstrated enhanced tumour cell kill with a combination of the MDM2 antagonist Nutlin and adenovirus-mediated p53 gene therapy. The authors also tested Nutlin in combination with oncolytic adenovirus-infected cancer cells, revealing accelerated viral progeny burst and a 10-1000-fold augmented eradication of p53 wildtype cancer cells. Cheok et al. (2007) also highlighted the potential success of Nutlins as therapeutic team members, but in a different manner. In this case, statistical measurement of the combination of cyclin-dependent inhibitors and Nutlin-3a demonstrated an additive effect on the reduction of cell viability and apoptotic induction in melanoma, colon carcinoma, breast adenocarcinoma, and hepatocarcinoma cells. Recently, Canner et al. (2009) demonstrated that treatment of rhabdomyosarcoma cells with the small molecule inhibitor MI-63 in combination with the known chemotherapeutic agent doxorubicin resulted in a synergistic effect. As doxorubicin may act in a p53-independent manner, the authors hypothesized that a combination treatment with MI-63 would potentiate each drug's anti-proliferative effects. In accordance with this, $20 \mathrm{nM}$ of doxorubicin in combination with $2000 \mathrm{nM} \mathrm{Ml-63}$ (day 1), showed a $49 \%$ increase in the fraction of cells affected by treatment when compared with the expected additive effect. Clinical trials will be necessary to evaluate such combinatorial effects for future therapeutic usage.

MicroRNAs (miRNAs) are small (18-25 nt), noncoding RNAs that function by controlling protein expression of other genes (Metias et al., 2009). miRNAs have recently stolen some thunder from small interfering RNAs (siRNAs; Campbell and Choy, 2005) as potential diagnostic and therapeutic tools. Specific miRNAs have been identified as inappropriately expressed in a variety of different tumours, leading to the speculation of linkage to cancer (Chari et. al., 2009). Several members of the miRNA-34 family have been shown to be downstream mediators of p53-induced apoptosis, cell cycle arrest, and senescence (Bommer et al., 2007; Chang et al., 2007; Corney et al., 2007; He et al., 2007; Raver-Shapira et al., 2007; Chari et al., 2009). Recently, the presence of a positive feedback loop was demonstrated in which p53 upregulated miRNA-34a, which then repressed the NAD-dependent deacetylase silent information regulator 1 (SIRT1), resulting in increased levels of p53 and amplification of the apoptotic signal (Yamakuchi et al., 2008). Such observations provide the impetus to move forward with manipulation of microRNAs for the development of p53-based anti-cancer treatments.

Published in late 2009, results from five independent laboratories identified p53 as a critical checkpoint during 
the multifactor reprogramming process whereby induced pluripotent stem cells are derived from differentiated adult cells (Hong et al., 2009; Kawamura et al., 2009; Li et al., 2009; Marion et al., 2009; Utikal et al., 2009). Absence of functional p53 enhanced the yield of induced pluripotent stem cells in each case, implicating p53 as a major gatekeeper of self-renewal (Aparicio and Eaves, 2009). This both complicates and enhances the role p53 may play in anti-cancer therapies. For example, if cancer is shown to arise directly through reprogramming-like processes, then further studies into reprogramming and the subsequent role of p53 may eventually point towards new, effective treatment for cancers (Krizhanovsky and Lowe, 2009).

Hainaut and Wiman (2009) stress the need for large, structured clinical trials in which patients with defined p53 status are specifically recruited, randomly assigned to predetermined treatment regimens, and followed up for long-term therapeutic and clinical endpoints. They advocate that detailed understanding of the clinical significance of p53 status will come from pooled analyses and metaanalyses assessing the strength of evidence across large data sets and different study contexts. This restructuring and amalgamation of clinical trials will expedite the process for determining the prognostic and predictive value of p53 mutations, as well as contribute to the eventual pharmacological control of p53 in cancer therapy, improving both survival and quality of life for cancer patients.

In concert with the restructuring of clinical trials, the strengthening and integration of current comprehensive online knowledgebases and datasets (Lim et al., 2007; International Agency for Research on Cancer TP53 database, http://www-p53.iarc.fr/) will permit rapid access to all relevant p53-related information (Hainaut and Wiman, 2009). The collection and dissemination of such a broad spectrum of research will provide insight into the interconnectedness of biological processes and allow rapid correlation with clinical data, accelerating the impact on disease diagnosis and treatment.

\section{Summary}

Time will tell whether p53 will fulfill its promise of playing a leading role in anti-cancer therapies. Regardless, the amassed knowledge of p53 biology provides a valuable resource for uncovering new ways to approach and manage cancer.

\section{Acknowledgements}

This work was supported by a Natural Sciences and Engineering Research Council Discovery Grant \#138216-09 to FYMC.

\section{References}

Alsafadi, S., Tourpin, S., Andre, F., Vassal, G., and Ahomadegbe, J.C. (2009). P53 family: at the crossroads in cancer therapy. Curr. Med. Chem. [epub ahead of print].

Aparicio, S. and Eaves, C.J. (2009). p53: a new kingpin in the stem cell arena. Cell 138, 1060-1062.

Baker, S.J., Fearon, E.R., Nigro, J.M., Hamilton, S.R., Preisinger, A.C., Jessup, J.M., vanTuinen, P., Ledbetter, D.H., Barker, D.F., Nakamura, Y., White, R., and Vogelstein, B. (1989). Chromosome 17 deletions and p53 gene mutations in colorectal carcinomas. Science 244 , 217-221.
Bommer, G.T., Gerin, I., Feng, Y., Kaczorowski, A.J., Kuick, R., Love, R.E., Zhai, Y., Giordano, T.J., Qin, Z.S., Moore, B.B., MacDougald, O.A., Cho, K.R., and Fearon, E.R. (2007). p53-mediated activation of miRNA34 candidate tumor-suppressor genes. Curr. Biol. 17, 1298-1307.

Bouchet, B.P., de Fromentel, C.C., Puisieux, A., and Galmarini, C.M. (2006). p53 as a target for anti-cancer drug development. Crit. Rev. Oncol. Hematol. 58, 190-207.

Burdelya, L.G., Komarova, E.A., Hill, J.E., Browder, T., Tararova, N.D., Mavrakis, L., Dicorleto, P.E., Folkman, J., and Gudkov, A.V. (2006). Inhibition of p53 response in tumour stroma improves efficacy of anticancer treatment by increasing antiangiogenic effects of chemotherapy and radiotherapy in mice. Cancer Res. 66, 9356-9361.

Campbell, T.N. and Choy, F.Y.M. (2005). RNA interference: past, present and future. Curr. Issues Mol. Biol. 7, 1-6.

Canner, J.A., Sobo, M., Ball, S., Hutzen, B., de Angelis, S., Willis, W., Studebaker, A.W., Ding, K., Wang, S., Yang, D., and Lin, J. (2009). MI-63: a novel small molecular inhibitor targets MDM2 and induces apoptosis in embryonal and alveolar rhabdomyosarcoma cells with wild-type p53. Brit. J. Cancer 101, 774-781.

Chang, C., Simmons, D.T., Martin, M.A., and Mora, P.T. (1979). Identification and partial characterization of new antigens from simian virus 40-transformed mouse cells. J. Virol. 31, 463-471.

Chang, T.C., Wentzel, E.A., Kent, O.A., Ramachandran, K., Mullendore, M., Lee, K.H., Feldmann, G., Yamakuchi, M., Ferlito, M., Lowenstein, C.J., Arking, D.E., Beer, M.A., Maitra, A., and Mendell, J.T. (2007). Transactivation of miR-34a by p53 broadly influences gene expression and promotes apoptosis. Mol. Cell 26, 745-752.

Chari, N.S., Pinaire, N.L., Thorpe, L., Medeiros, L.J., Routbort, M.J., and McDonnell, T.J. (2009). The p53 tumor suppressor network in cancer and the therapeutic modulation of cell death. Apoptosis 14, 336-347.

Cheok, C.F., Dey, A., and Lane, D.P. (2007). Cyclindependent kinase inhibitors sensitize tumor cells to nutlin-induced apoptosis: a potent drug combination. Mol. Cancer Res. 5, 1133-1145.

Corney, D.C., Flesken-Nikitin, A., Godwin, A.K., Wang, W., and Nikitin, A.Y. (2007). MicroRNA-34b and MicroRNA$34 \mathrm{c}$ are targets of p53 and cooperate in control of cell proliferation and adhesion-independent growth. Cancer Res. 67, 8433-8438.

Eliyahu, D., Raz, A., Gruss, P., Givol, D., and Oren, M. (1984). Participation of p53 cellular tumour antigen in transformation of normal embryonic cells. Nature 312 , 646-649.

Finlay, C.A., Hinds, P.W., and Levine, A.J. (1989). The p53 proto-oncogene can act as a suppressor of transformation. Cell 57, 1083-1093.

Fuster, J.J., Sanz-Gonzalez, S.M., Moll, U.M., and Andres, V. (2007). Classic and novel roles of p53: prospects for anticancer therapy. Trends Mol. Med. 13, 192-199.

Graat, H.C.A., Carette, J.E., Schagen, F.H.E., Vassilev, L.T., Gerritsen, W.R., Kaspers, G.J.L., Wuisman, P.I.J.M., and van Beusechem, V.W. (2007). Enhanced tumor kill by combined treatment with a small-molecule antagonist of mouse double minute 2 and adenoviruses encoding p53. Mol. Cancer Ther. 6, 1552-1561. 
Gudkov, A.V. and Komarova, E.A. (2007). Dangerous habits of a security guard: the two faces of p53 as a drug target. Hum. Mol. Genet. 16, R67-R72.

Hainaut, P. and Wiman, K.G. (2009). 30 years and a long way into p53 research. Lancet Oncol. 10, 913-919.

He, I., He, X., Lim, L.P., de Stanchina, E., Xuan, Z., Liang, Y., Xue, W., Zender, L., Magnus, J., Ridzon, D., Jackson, A.L., Linsley, P.S., Chen, C., Lowe, S.W., Cleary, M.A., and Hannon, G.J. (2007). A microRNA component of the p53 tumor suppressor network. Nature 447, 1130-1134.

Hinds, P., Finlay, C., and Levine, A.J. (1989). Mutation is required to activate the p53 gene for cooperation with the ras oncogene and transformation. J. Virol. 63, 739-746.

Hong, H., Takahashi, K., Ichisaka, T., Aoi, T., Kanagawa, O., Nakagawa, M., Okita, K., and Yamanaka, S. (2009). Suppression of induced pluripotent stem cell generation by the p53-p21 pathway. Nature 460, 1132-1135.

Kawamura, T., Suzuki, J., Wang, Y.V., Menendez, S., Morera, L.B., Raya, A., Wahl, G.M., and Belmonte, J.C.I. (2009). Linking the p53 tumour suppressor pathway to somatic cell reprogramming. Nature 460, 1140-1144.

Kress, M., May, E., Cassingena, R., and May, P. (1979). Simian virus 40-transformed cells express new species of proteins precipitable by anti-simian virus 40 tumor serum. J. Virol. 31, 472-483.

Krizhanovsky, V. and Lowe, S.W. (2009). The promises and perils of p53. Nature 460, 1085-1086.

Lane, D.P. (1992). Cancer. p53, guardian of the genome. Nature 358, 15-16.

Lane, D.P. and Crawford, L.V. (1979). T antigen is bound to a host protein in SV40-transformed cells. Nature 278, 261-263.

Li, H., Collado, M., Villasante, A., Strati, K., Ortega, S., Cañamero, M., Blasco, M.A., and Serrano, M. (2009). The Ink4/Arf locus is a barrier for iPS cell reprogramming. Nature 460, 1136-1139.

Lim, Y.P., Lim, T.T., Chan, Y.L., Song, A.C., Yeo, B.H., Vojtesek, B., Coomber, D., Rajagopal, G., and Lane, D. (2007). The p53 knowledgebase: an integrated information resource for p53 research. Oncogene 26, 1517-1521.

Linzer, D.I. and Levine, A.J. (1979). Characterization of a $54 \mathrm{~K}$ dalton cellular SV40 tumor antigen present in SV40transformed cells and uninfected embryonal carcinoma cells. Cell 17, 43-52.

Marión, R.M., Strati, K., Li, H., Murga, M., Blanco, R., Ortega, S., Fernandez-Capetillo, O., Serrano, M., and Blasco,
M.A. (2009). A p53-mediated DNA damage response limits reprogramming to ensure iPS cell genomic integrity. Nature 460, 1149-1153.

Melero, J.A., Stitt, D.T., Mangel, W.F., and Carroll, R.B. (1979). Identification of new polypeptide species (48- 55 $\mathrm{K}$ ) immunoprecipitable by antiserum to purified large $T$ antigen and present in SV40-infected and -transformed cells. Virology 93, 466-480.

Metias, S.M., Lianidou, E., and Yousef, G.M. (2009). MicroRNAs in clinical oncology: at the crossroads between promises and problems. J. Clin. Pathol. 62, 771-776.

Parada, L.F., Land, H., Weinberg, R.A., Wolf, D., and Rotter, V. (1984). Cooperation between gene encoding p53 tumour antigen and ras in cellular transformation. Nature 312, 649-651.

Raver-Shapira, N., Marciano, E., Meiri, E., Spector, Y., Rosenfeld, N., Moskovits, N., Bentwich, Z., and Oren, M. (2007). Transcriptional activation of miR-34a contributes to p53-mediated apoptosis. Mol. Cell. 26, 731-743.

Shangary, S. and Wang, S. (2009). Small-molecule inhibitors of the MDM2-p53 protein-protein interaction to reactivate p53 function: a novel approach for cancer therapy. Ann. Rev. Pharmacol. Toxicol. 49, 223-241.

Utikal, J., Polo, J.M., Stadtfeld, M., Maherali, N., Kulalert, W., Walsh, R.M., Khalil, A., Rheinwald, J.G., and Hochedlinger, K. (2009). Immortalization eliminates a roadblock during cellular reprogramming into iPS cells. Nature 460, 1145-1148.

Vazquez, A., Bond, E.E., Levine, A.J., and Bond, G.L. (2008). The genetics of the p53 pathway, apoptosis and cancer therapy. Nature Rev. Drug Discovery 7, 979-987.

Ventura, A., Kirsch, D.G., McLaughlin, M.E., Tuveson, D.A., Grimm, J., Lintault ,L., Newman, J., Reczek, E.E., Weissleder, R., and Jacks, T. (2007). Restoration of p53 function leads to tumor regression in vivo. Nature 445 , 661-665.

Xue, W., Zender, L., Miething, C., Dickins, R.A., Hernando, E., Krizhanovsky, V., Cordon-Cardo, C., and Lowe, S.W. (2007). Senescence and tumor clearance is triggered by p53 restoration in murine liver carcinomas. Nature 445, 656-660.

Yamakuchi, M., Ferlito, M., and Lowenstein, C.J. (2008). miR34a repression of SIRT1 regulates apoptosis. Proc. Natl. Acad. Sci. USA 105, 13421-13426. 


\section{Further Reading}

Caister Academic Press is a leading academic publisher of advanced texts in microbiology, molecular biology and medical research. Full details of all our publications at caister.com

- MALDI-TOF Mass Spectrometry in Microbiology Edited by: M Kostrzewa, S Schubert (2016) www.caister.com/malditof

- Aspergillus and Penicillium in the Post-genomic Era Edited by: RP Vries, IB Gelber, MR Andersen (2016) www.caister.com/aspergillus2

- The Bacteriocins: Current Knowledge and Future Prospects Edited by: RL Dorit, SM Roy, MA Riley (2016)

www.caister.com/bacteriocins

- Omics in Plant Disease Resistance Edited by: V Bhadauria (2016) www.caister.com/opd

- Acidophiles: Life in Extremely Acidic Environments Edited by: R Quatrini, DB Johnson (2016) www.caister.com/acidophiles

- Climate Change and Microbial Ecology: Current Research and Future Trend

Edited by: J Marxsen (2016)

www.caister.com/climate

- Biofilms in Bioremediation: Current Research and Emerging Technologies

Edited by: G Lear (2016)

www.caister.com/biorem

- Microalgae: Current Research and Applications Edited by: MN Tsaloglou (2016) www.caister.com/microalgae

- Gas Plasma Sterilization in Microbiology: Theory, Applications, Pitfalls and New Perspectives Edited by: H Shintani, A Sakudo (2016) www.caister.com/gasplasma

- Virus Evolution: Current Research and Future Directions Edited by: SC Weaver, M Denison, M Roossinck, et al. (2016) www.caister.com/virusevol

- Arboviruses: Molecular Biology, Evolution and Control Edited by: N Vasilakis, DJ Gubler (2016) www.caister.com/arbo

- Shigella: Molecular and Cellular Biology Edited by: WD Picking, WL Picking (2016) www.caister.com/shigella

-Aquatic Biofilms: Ecology, Water Quality and Wastewater Treatment

Edited by: AM Romaní, H Guasch, MD Balaguer (2016)

www.caister.com/aquaticbiofilms

- Alphaviruses: Current Biology

Edited by: S Mahalingam, L Herrero, B Herring (2016)

www.caister.com/alpha

- Thermophilic Microorganisms

Edited by: F Li (2015)

www.caister.com/thermophile
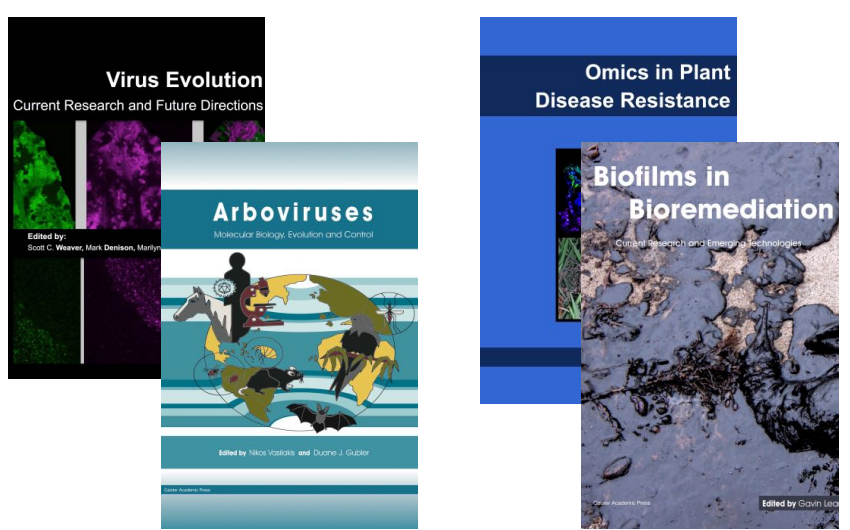
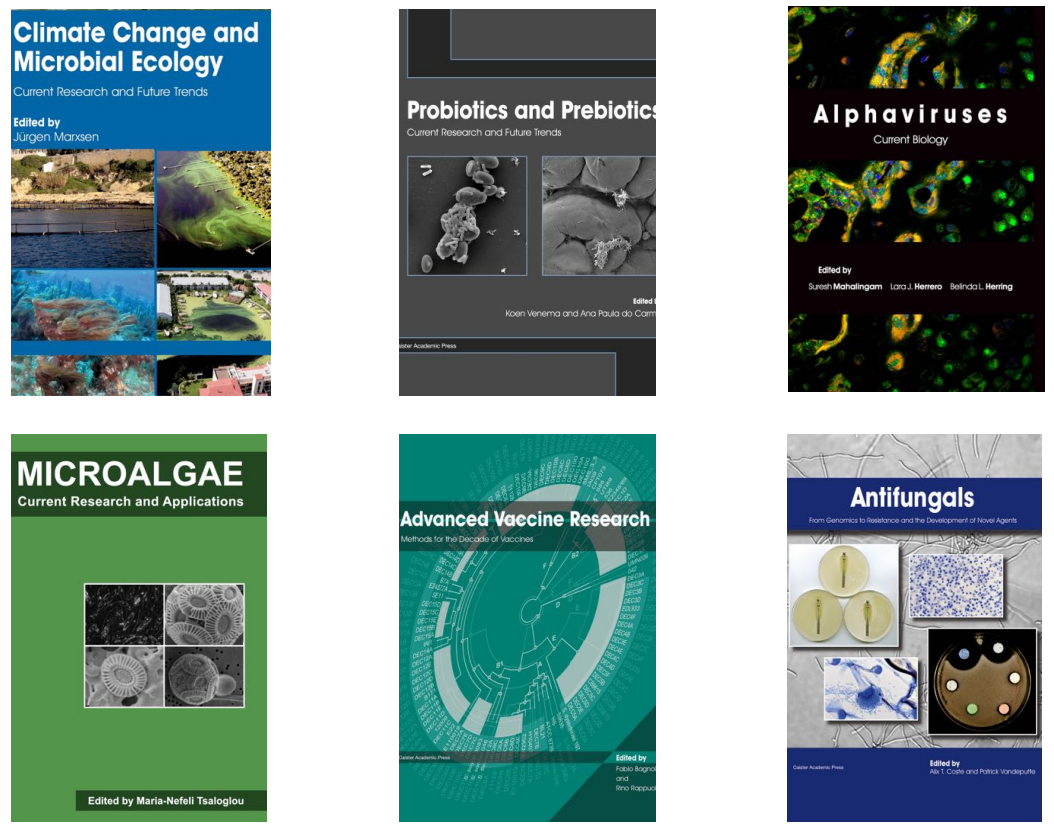

- Flow Cytometry in Microbiology: Technology and Applications Edited by: MG Wilkinson (2015) www.caister.com/flow

- Probiotics and Prebiotics: Current Research and Future Trends Edited by: K Venema, AP Carmo (2015) www.caister.com/probiotics

- Epigenetics: Current Research and Emerging Trends Edited by: BP Chadwick (2015) www.caister.com/epigenetics2015

- Corynebacterium glutamicum: From Systems Biology to Biotechnological Applications

Edited by: A Burkovski (2015)

www.caister.com/cory2

- Advanced Vaccine Research Methods for the Decade of Vaccines

Edited by: F Bagnoli, R Rappuoli (2015)

www.caister.com/vaccines

- Antifungals: From Genomics to Resistance and the Development of Novel Agents

Edited by: AT Coste, P Vandeputte (2015)

www.caister.com/antifungals

- Bacteria-Plant Interactions: Advanced Research and Future Trends Edited by: J Murillo, BA Vinatzer, RW Jackson, et al. (2015) www.caister.com/bacteria-plant

\section{- Aeromonas}

Edited by: J Graf (2015)

www.caister.com/aeromonas

- Antibiotics: Current Innovations and Future Trends

Edited by: S Sánchez, AL Demain (2015)

www.caister.com/antibiotics

- Leishmania: Current Biology and Contro Edited by: S Adak, R Datta (2015) www.caister.com/leish2

- Acanthamoeba: Biology and Pathogenesis (2nd edition) Author: NA Khan (2015)

www.caister.com/acanthamoeba2

- Microarrays: Current Technology, Innovations and Applications Edited by: Z He (2014)

www.caister.com/microarrays2

- Metagenomics of the Microbial Nitrogen Cycle: Theory, Methods and Applications

Edited by: D Marco (2014)

www.caister.com/n2 